https://doi.org/10.15407/frg2020.04.279

UDC (581.1:582.926.2):661.162.65/66

\title{
THE EFFECT OF GROWTH PROMOTORS AND RETARDANTS ON THE MORPHOGENESIS, PHOTOSYNTHESIS AND PRODUCTIVITY OF TOMATOES (LYCOPERSICON ESCULENTUM MILL.)
}

\author{
V.V. ROHACH ${ }^{1}$, D.A. KIRIZIY' ${ }^{2}$, O.O. STASIK ${ }^{2}$, S. MICKEVICIUS ${ }^{3}$, T.I. ROHACH ${ }^{1}$ \\ ${ }^{1}$ Mikhail Kotsyubinsky Vinnytsya State Pedagogical University \\ 32 Ostrozhsky St., Vinnytsya, 21100, Ukraine \\ e-mail: rogachv@ukr.net \\ ${ }^{2}$ Institute of Plant Physiology and Genetics, National Academy of Sciences of \\ Ukraine \\ 31/17 Vasylkivska St., Kyiv, 03022, Ukraine \\ ${ }^{3}$ Vytautas Magnus University, Faculty of Natural Sciences \\ 8-212 Vileikos St., Kaunas, 44404, Lithuania
}

There were studied the peculiarities of growth processes, the formation of the leaf apparatus, its mesostructure and photosynthetic activity, as well as the biological productivity of the Bobcat hybrid tomato plants under the influence of synthetic analogues of growth promoting hormones - 1-naphthaleneacetic acid (1-NAA), gibberellic acid $\left(\mathrm{GA}_{3}\right)$, 6-benzylaminopurine (6-BAP), and retardants chloromequate chloride (CCC-750), tebuconazole (EW-250), ethephon (2chloroethylphosphonic acid, 2-CEPA), which differ in the action mechanism. It was revealed that growth promotors increased, and retardants reduced the tomato plants height. It was established that 1-NAA, GA, and CCC-750 increased the leaf number on the plant, while under 2-CEPA treatment, the index was less than the control, and under the EW-250 action it remained practically unchanged. All growth regulators, except 2-CEPA, increased the leaf blades number, the fresh weight, and leaf area. All growth promotors increased the whole plant dry weight, while the retardants EW-250 and CCC-750 did not affect this index, and 2-CEPA significantly reduced it. All retardants and 6-BAP significantly increased the total chlorophyll content in tomato leaves, while under the action of $\mathrm{GA}_{3}$ this index decreased. The retardants EW-250 and CCC-750, and the growth promotor 6-BAP contributed to the thickening of the tomato leaf chlorenchyma, and the ethylene producer 2-CEPA reduced it. Under the influence of all growth regulators, except 2-CEPA, the volume of columnar parenchyma cells increased. It was established that at the stage of fruit formation onset, all growth regulators, except 1-NAA, increased the rate of $\mathrm{CO}_{2}$ assimilation, photorespiration, dark respiration and transpiration. All growth regulators, except 2-CEPA, contributed to the increase in tomatoes yield, while the use of the growth promotor 6-BAP and the retardant EW-250 proved to be the most effective.

Key words: Lycopersicon esculentum Mill., tomatoes, growth promotors, retardants, morphogenesis, leaf apparatus, mesostructure, chlorophyll, photosynthesis, respiration, productivity.

Citation: Rohach V.V., Kiriziy D.A., Stasik O.O., Mickevicius S., Rohach T.I. The effect of growth promotors and retardants on the morphogenesis, photosynthesis and productivity of tomatoes (Lycopersicon esculentum Mill.). Fiziol. rast. genet., 2020, 52,
No. 4, pp. 279-294. https://doi.org/10.15407/frg2020.04.279 
Improving crop productivity is an important task for plant biologists. This is achieved both by creating new varieties and hybrids by breeding and biotechnological methods, and by developing new technologies for their cultivation, which in fact is one of the tasks of plant physiology. One of the important elements of the latter is the use of growth regulators, especially those that affect assimilation processes and the redistribution of assimilates in the plants source-sink system [1-3]. The study of the influence of growth regulators with various directions and action mechanisms on growth, morphogenesis, photosynthetic activity and yield is an important theoretical and practical task of modern plant physiology.

All growth regulators, depending on the direction of their action on plant organisms, can be divided into two groups - plant growth and development promotors, and inhibitors of these processes. The effect of the former is associated with the activation of growth processes and accelerated development with a subsequent increase in the demand on assimilates toward photosynthetic apparatus, which will provide more intensive formation of tissues and organs [4-9]. Most of these compounds are natural preparations or synthetic analogues of the phytohormones - auxins, cytokinins and gibberellins.

The influence of the second group substances is associated, first of all, with the plants linear growth inhibition with the subsequent redistribution of plastic substances in the source-sink system to economically valuable organs. Inhibitors of the gibberellins activity in a plant organism are most widely used in agricultural practice [10-14]. These substances cause similar anatomical and morphological changes, but differ in the mechanism of action. According to this principle, retardants can be divided into two groups: substances that interrupt the gibberellins biosynthesis, and substances that neutralize the growth promoting effect of gibberellins without interrupting biosynthesis. The first group includes quaternary ammonium compounds and triazole derivatives, and the second group includes ethylene producers. Quaternary ammonium compounds interrupt the biosynthesis of gibberellins in only one unit, in particular, chlorocholine chloride (CCC) inhibits the activity of ent-kaurene synthase at the stage of conversion of geranylgeraniol diphosphate to copalyl pyrophosphate. The effect of triazole derivatives on the growth of plants axial organs is based on the inhibition of the ent-kaurene synthase activity, and suppression of gibberellins biosynthesis at the stage of geranylgeraniol diphosphate conversion to copalyl pyrophosphate and subsequently to ent-kaurene. Ethylene producers, unlike quaternary ammonium compounds and triazole derivatives, do not affect the gibberellins synthesis, but by blocking the hormonereceptor complex formation, they can inhibit the activity of already synthesized hormones of this class.

It is known that morpho-physiological changes under the influence of growth regulators cause the rearrangement of the leaves as well as whole photosynthetic apparatus, affect its activity, which also changes the supply of plants with assimilates and leads to their redistribution in the source-sink system $[2,12,15]$.

So, two fundamentally different approaches to the growth processes regulation - promotion, or selective inhibition of growth can ultimately give a similar effect - increasing the biological productivity of plants, yield 
and quality of agricultural products. Moreover, the result depends not only on the chemical nature of the active substance, but also on its dose, stage of development and biological characteristics of a particular crop.

Representatives of Solanaceae family occupy a prominent place among the main vegetable crops. Therefore, the problem of increasing their productivity with the help of growth regulators is very relevant [16-20]. In particular, for tomatoes it has long been known the ethylene producers use to accelerate their ripening in order to mechanize the fruits gathering. There are also works on the study of the influence on their growth, sourcesink relations, and the productivity of individual growth promotors and retardants [21]. But comprehensive studies of all the main plant growth promotors and common classes of retardants influence on the tomato plants morpho-physiological parameters, and the assimilation activity of their leaves as crop production process components are unknown to us.

The aim of the work was to elucidate the peculiarities of growth processes, the formation of the leaf apparatus, its mesostructure and photosynthetic activity, as well as the formation of productivity elements of tomato plants under the influence of synthetic analogues of the main growth promoting hormones - auxins, cytokinins and gibberellins, and retardants - representatives of the quaternary ammonium compounds, triazole derivatives and ethylene producers classes.

\section{Materials and methods}

Plants were grown under the conditions of a soil culture pot experiment in opaque plastic vessels of 10 liters volume under natural light. Soil - gray forest podzolized coarse-dust medium-loamy. A soil-sand mixture was prepared in a ratio of $3: 1$. Soil moisture during the growing season was maintained at $60 \% \mathrm{FC}$.

Tomato plants of the Bobcat hybrid at the beginning of the budding stage once were sprayed until the leaves are completely wetted with $0.005 \%$ solutions of 1-naphthaleneacetic acid (1-NAA), gibberellic acid $\left(\mathrm{GA}_{3}\right)$ and 6-benzylaminopurine (6-BAP), and also $0.25 \%$ solution of chloromequate chloride (CCC-750), $0.025 \%$ solution of tebuconazole (EW-250), and $0.15 \%$ solution of ethephon (2-chloroethylphosphonic acid, 2-CEPA). Control plants were sprayed with water. Repeat of pot experiment was ten times.

Morphological parameters were studied every 10 days. The individual organs were weighed on a laboratory balance. Leaf area was determined by the gravimetric method [22]. The leaf mesostructural organization was studied during the period of carpogenesis on fixed material [23]. To fix the material, a mixture of equal parts of ethyl alcohol, glycerol, water with the addition of $1 \%$ formalin was used. The sizes of individual chlorenchyma cells were determined using preparations obtained by partial maceration of leaf tissues [24]. The macerating agent was a $5 \%$ solution of acetic acid in $2 \mathrm{M}$ hydrochloric acid. For anatomical analysis, leaves of the middle tier were selected, which completed the growth. The parameters of anatomical elements were measured using a microscope Mikmed-1 and an ocular micrometer MOV 1-15×. Repeat of measurements was thirty five times.

The total chlorophyll content was determined in fresh material by the spectrophotometric method [25] at five repetitions. 
$\mathrm{CO}_{2}$ exchange rates were recorded under controlled conditions at a facility mounted on the basis of the GIAM-5M infrared gas analyzer, switched on according to a differential circuit. The middle blade of the leaf not separated from the plant was placed in a thermostatically controlled $\left(25^{\circ} \mathrm{C}\right)$ chamber $3 \times 7 \mathrm{~cm}$ in size and illuminated $\left(1800 \mu \mathrm{mol} /\left(\mathrm{m}^{2} \cdot \mathrm{s}\right)\right.$ PAR $)$ with a TA-11 50W LED floodlight with a color temperature of $5200 \mathrm{~K}$. Conditioned atmospheric air was blown through the chamber at a rate of $1 \mathrm{l} / \mathrm{min}$. The net assimilation rate was recorded in 40-50 min after the start of illumination, when the rate of $\mathrm{CO}_{2}$ absorption reached a stationary level. The photorespiration rate was estimated by the $\mathrm{CO}_{2}$ burst out of leaf for $1 \mathrm{~min}$ after turning off the light. The dark respiration rate was recorded in $10 \mathrm{~min}$ after turning off the light. The transpiration rate was measured by a portable gas analyzer EGM 5 (USA) by the difference in air humidity at the inlet and outlet of the chamber. The calculation of gas exchange indices was carried out according to standard methods [26]. Repeat of measurements was three times.

The text, tables and graphs show the arithmetic mean values and their standard errors. The results were processed statistically using the computer program Statistica-6.0. One-way analysis of variance was used (differences between the mean values were calculated by the ANOVA criterion, they were considered significant at $\mathrm{p} \leq 0.05$ ).

\section{Results and discussion}

An important morphometric characteristic of a plant is its height. It was established that growth regulators differently influenced the linear sizes of Bobcat hybrid tomato plants. At the end of the study period, plants treated with $\mathrm{GA}_{3}$ were the highest among the variants with growth-promoting preparations. This substance increased plant height by $24 \%$ compared to the control (Fig. 1). After the application of 1-NAA, the linear sizes of tomato plants increased by $18 \%$, and with 6 -BAP - by $10 \%$. The antigibberellin preparations 2-CEPA, EW-250, and CCC-750 reduced the plant height compared to the control by $37 \%, 9 \%$, and $11 \%$, respectively. The results of our studies are consistent with published data on the influ-

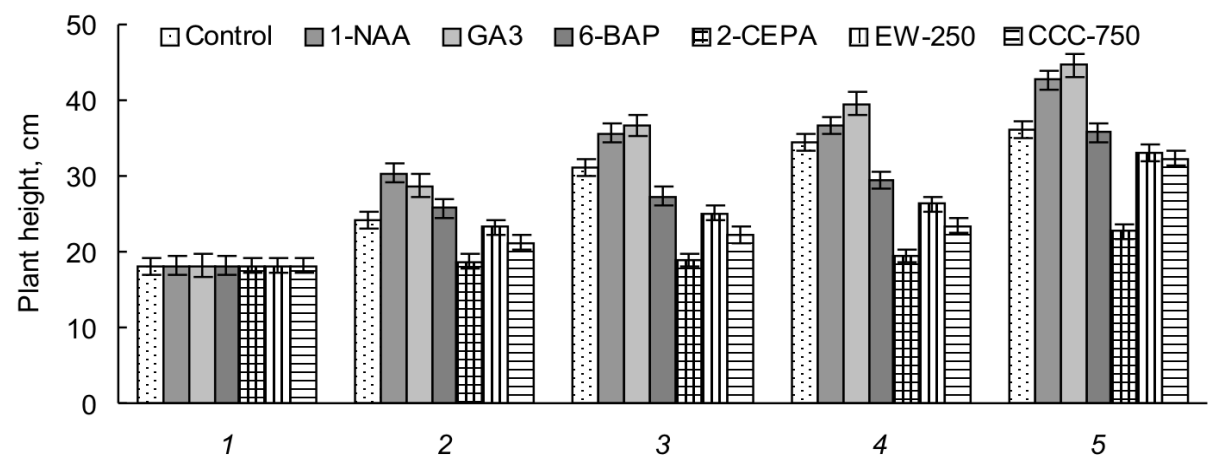

Fig. 1. Effect of growth regulators on the tomato plants height (plants were treated at the budding stage on June 08, 2019):

$1-$ day of treatment; $2-10$ th day after treatment; $3-20$ th day after treatment; $4-30$ th day after treatment; $5-40$ th day after treatment 


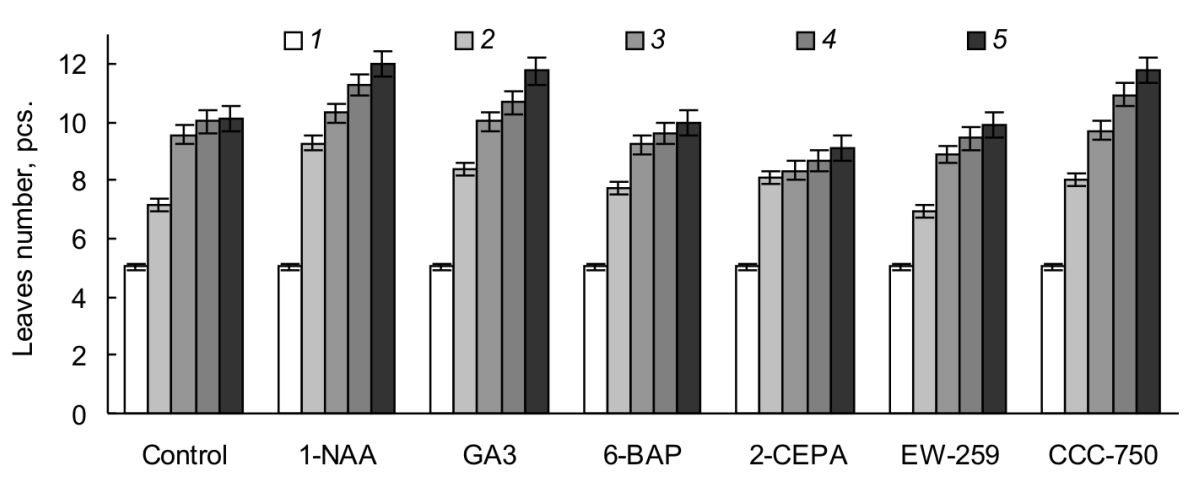

Fig. 2. Effect of growth regulators on the tomato plants leaves number (plants were treated at the budding stage on June 08, 2019):

$1-$ day of treatment; $2-10$ th day after treatment; $3-20$ th day after treatment; $4-30$ th day after treatment; $5-40$ th day after treatment

ence of growth regulators with various action mechanisms on the cultivated and wild plants growth rate [1-3].

Since the main assimilates source in the plant is the leaf, it is important to establish the effect of multidirectional growth regulators on the leaf apparatus. It was revealed that during the period of carpogenesis the greatest leaves number was after treatment with 1-NAA (Fig. 2). The index increased compared to the control by $19 \%$. CCC-750 and $\mathrm{GA}_{3}$ increased the leaves number by $16 \%$. But under the influence of 2-CEPA, a decrease of $10 \%$ was observed, and the EW-250 had practically no effect on this index.

The average leaf blades number on the imparipinnate leaf of this tomato hybrid changed somewhat differently (Fig. 3). It was the greatest after the application of 1-NAA (an increase by $29 \%$ compared to the control), 6-BAP (by $25 \%$ ) and EW-250 (by $22 \%$ ). Under the influence of $\mathrm{GA}_{3}$, the number of leaf blades increased by $12 \%$, and after CCC750 treatment - by $10 \%$. The use of 2-CEPA did not significantly change this index.

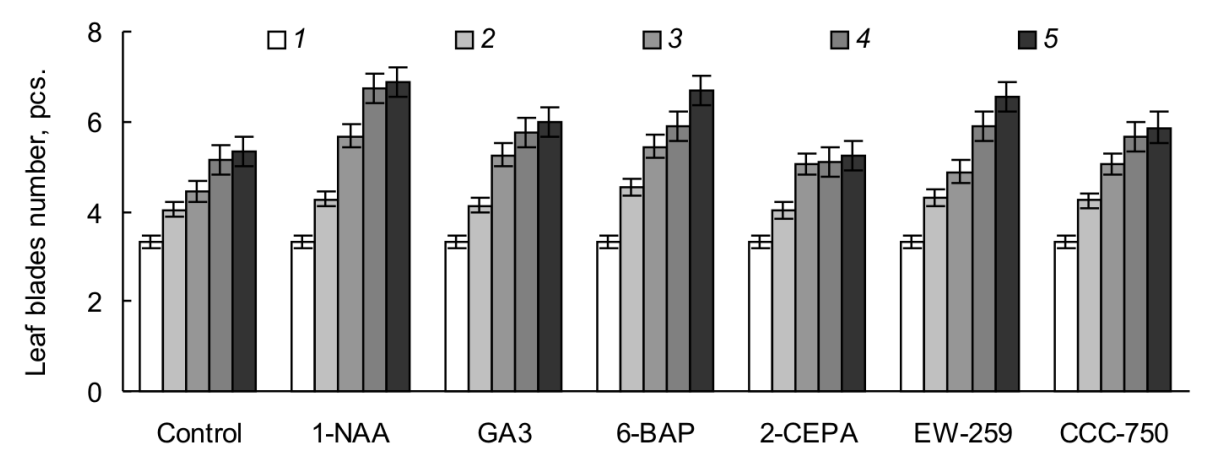

Fig. 3. Effect of growth regulators on the average leaf blades number on the imparipinnate leaf of Bobcat hybrid tomato plants (plants were treated at the budding stage on June 08, 2019):

1 - day of treatment; $2-10$ th day after treatment; $3-20$ th day after treatment; $4-30$ th day after treatment; $5-40$ th day after treatment 


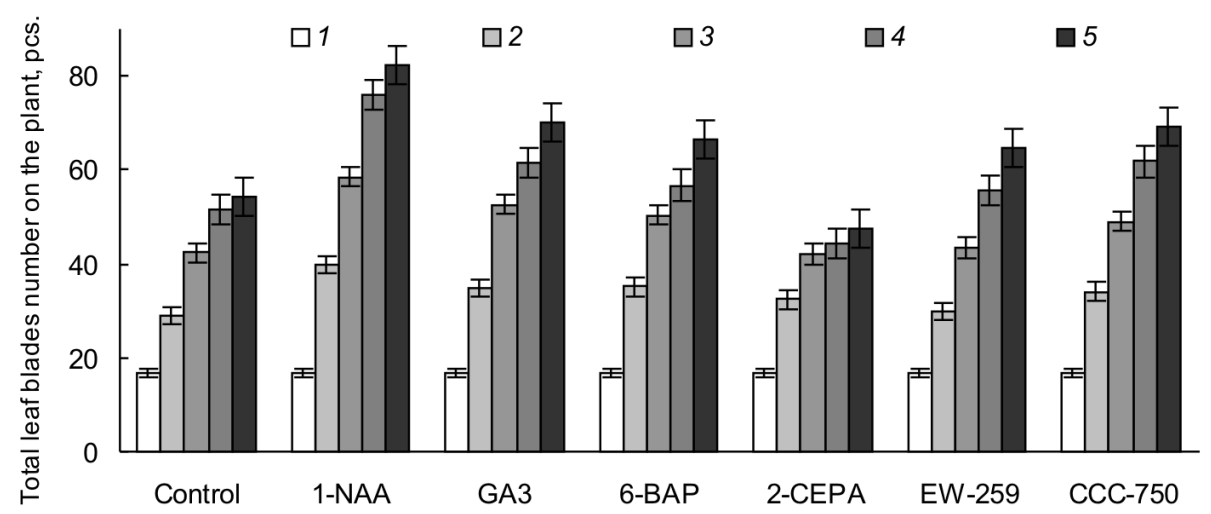

Fig. 4. Effect of growth regulators on the total leaf blades number on the tomato plants (plants were treated at the budding stage on June 08, 2019):

$1-$ day of treatment; $2-10$ th day after treatment; $3-20$ th day after treatment; $4-30$ th day after treatment; $5-40$ th day after treatment

In general, the total leaf blades number on the plant was the largest after treatment with 1-NAA. The index exceeded the control one by $52 \%$. After applying $\mathrm{GA}_{3}$, the index increased by $30 \%$, and with 6-BAP it increased by $23 \%$. An increase in the leaf blades number on the plant was also observed after plants treatment with CCC-750 (by $28 \%$ ) and EW-250 (by $20 \%$ ). Only 2-CEPA reduced this index by $12 \%$ compared to the control (Fig. 4).

According to published data, an increase in the leaves number under the influence of growth regulators was observed in Polygonum cuspidatum plants under the effect of $\mathrm{GA}_{3}$ [4], under the influence of treptolem in oil poppy plants [5], and oil flax [6]. The retardant uniconazole increased the leaves weight and number in soybean plants [27], and chloromequate chloride decreased their number in sunflower plants [28], while in rapeseed plants, the effect of paclobutrazol and dextrel on this index depended on the growing season weather conditions [13]. On tomato plants, it was shown that at the stage of formation and the green degree of fruits ripeness, the largest leaves number was formed under the effect of the tebuconazole and ethylene producer esphon, and from the stage of green to the brown degree of ripeness, this index increased significantly under gibberellin treatment [21].

One of the most important indices that affects a plant productivity is the leaf area. It is known that growth promotors, as a rule, increase this index, whereas when applying retardants on various cultures, the effect was ambiguous. Thus, under the influence of the 6-BAP, the leaf area increased in maize plants [7], as in the case of $\mathrm{GA}_{3}$ in sugarcane [29]. A similar results were observed on wheat plants treated with IAA, 2-NAA, and $\mathrm{GA}_{3}$, but the retardant Ppp333 reduced leaf area [1]. A decrease in the rape plants leaf area was observed under the action of the same retardant and ethylene producer dextrel [13]. Another triazole derivative, uniconazole, reduced soybean leaf area [27]. At the same time, onium retardant chloromequate chloride increased the sunflower plants leaf area [28], and paclobutrazole increased it in sweet potato plants [14]. On tomatoes it was 


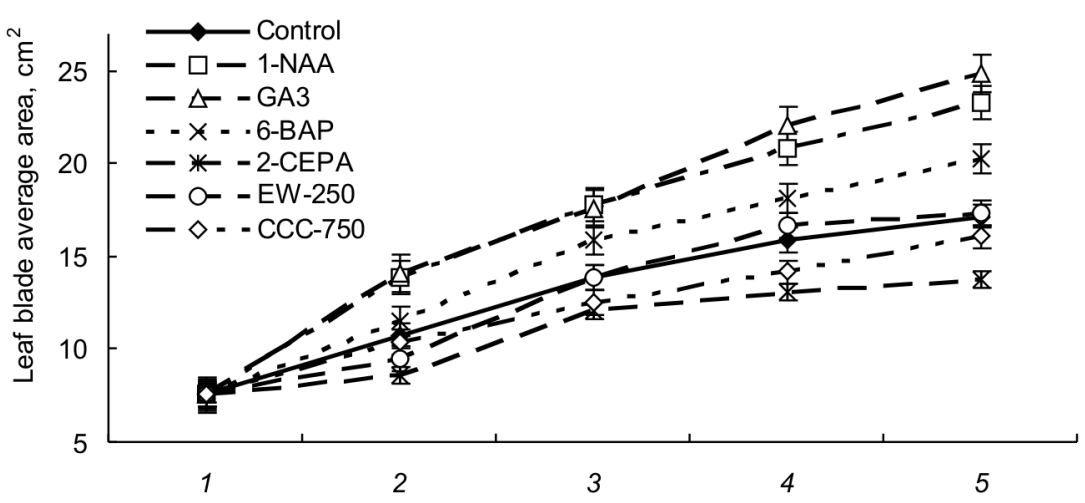

Fig. 5. Effect of growth regulators on the leaf blade average area (tomato plants were treated at the budding stage on June 08, 2019):

$1-$ day of treatment; $2-10$ th day after treatment; $3-20$ th day after treatment; $4-30$ th day after treatment; $5-40$ th day after treatment

shown that at the stage of green degree of fruits ripeness, the maximum leaf area was under tebuconazole and gibberellin treatment [21].

In our experiments, it was found that growth promotors increased the leaf blade average area. Most of all, the index increased after the use of $\mathrm{GA}_{3}$ and 1-NAA (respectively by $45 \%$ and $36 \%$ compared to the control) (Fig. 5). Retardants CCC-750 and EW-250 had almost no effect on the leaf blades area, and after 2-CEPA treatment it decreased by $20 \%$.

The total leaf surface area at the beginning of the fruit formation stage was the largest after $\mathrm{GA}_{3}$ and 1-NAA application. Under the influence of these preparations, the index was higher than in the control by 80 and $49 \%$, respectively (Fig. 6). After applying 6-BAP, the leaf area increased by $29 \%$, and the EW-250 and CCC-750 retardants increased this index by 7 and $13 \%$, respectively. After 2-CEPA treatment, the leaf surface area decreased by $26 \%$ compared to the control.

It was found that all growth promotors studied by us increased the leaves fresh weight (Table 1). Retardants EW-250 and CCC-750 showed a tendency to increase this index, and under 2-CEPA treatment it decreased by $41 \%$. Changes in the leaf apparatus structure positively affected other anatomical and morphological plant parameters. We found that all growth

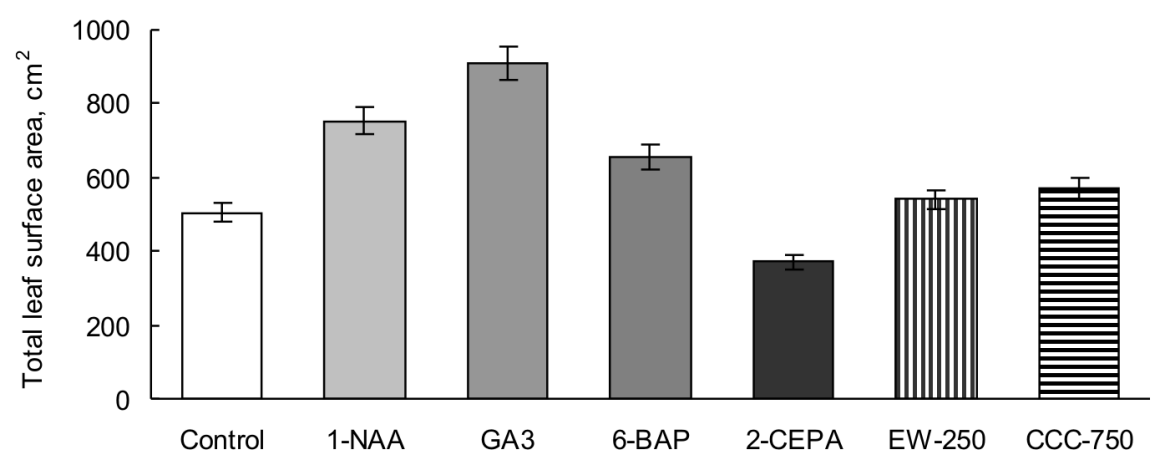

Fig. 6. Effect of growth regulators on the tomato plants total leaf surface area at the beginning of the fruit formation stage (plants were treated at the budding stage on June 08, 2019) 


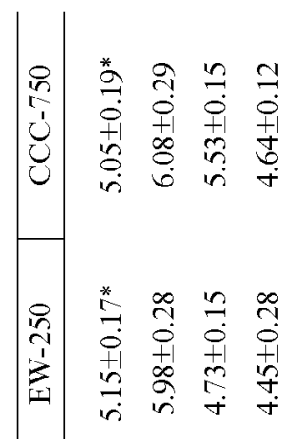

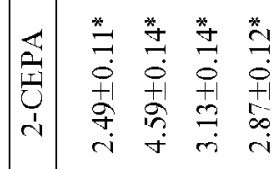<smiles>[AlH2]</smiles>

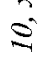

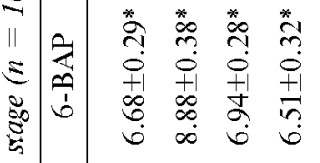

है

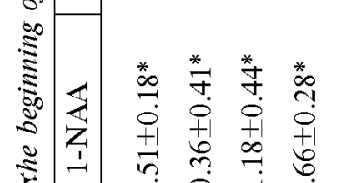

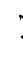

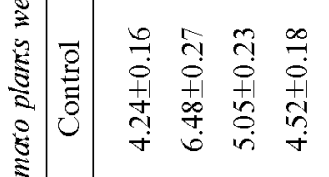

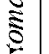

ธี้

s.

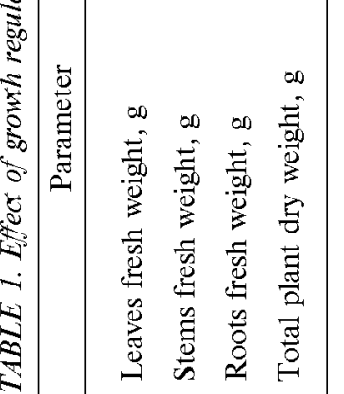

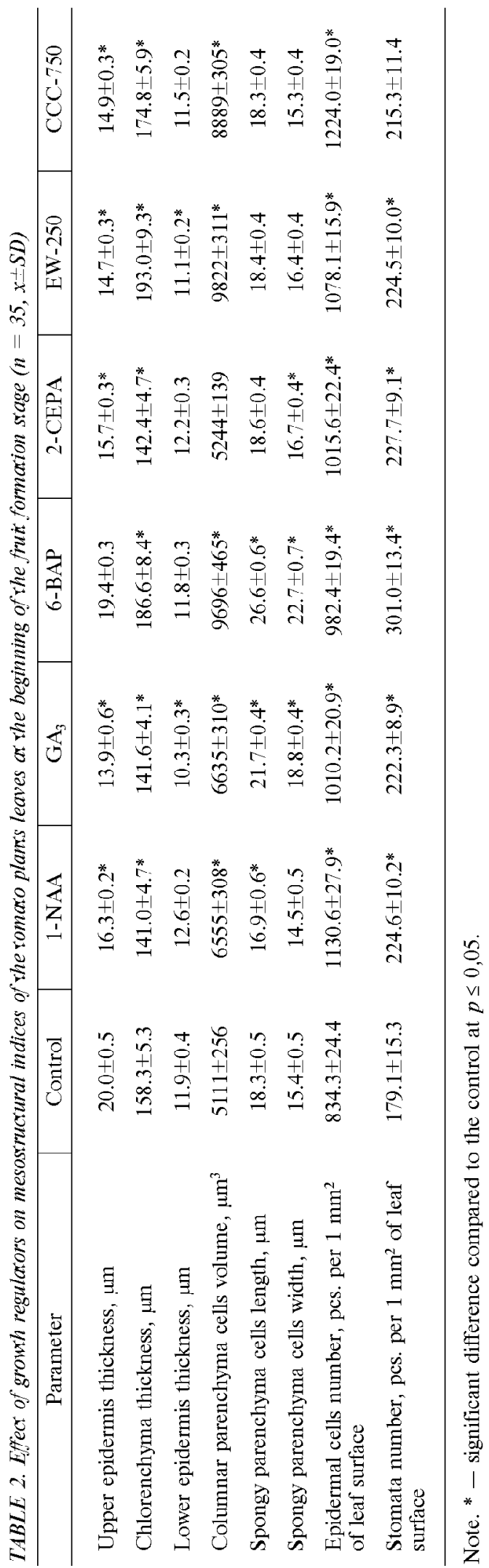

ISSN 2308-7099. Fiziol. rast. genet. 2020. T. 52. № 4 
promotors increased the stems and roots fresh weight. The indices increased the most significant after the $\mathrm{GA}_{3}$ and 1-NAA treatment. In particular, the stems and roots fresh weight increased 2.2 and 1.6 times, and 1.7 and 2.2 times, respectively. 6-BAP increased both parameters by 1.4 times. Under the effect of 2-CEPA, the stems and roots fresh weight decreased compared to the control by 29 and $38 \%$, respectively. Preparations EW-250 and CCC-750 showed a tendency to decrease the stems fresh weight, and the latter even slightly increased the roots weight. Literature sources contain information on the increase in the weight of vegetative organs both under the influence of growth promotors [29, 30], and under the influence of retardants [31]. It should be noted that in our experiments, under 1-NAA treatment the leaves proportion in the whole plant weight decreased by $24 \%$ (due to the predominant growth of stems and roots), $\mathrm{GA}_{3}$ and 2-CEPA did not significantly affect this index, and 6-BAP, CCC-750 and EW-250 increased it by 10, 13 and $21 \%$, respectively.

All three growth promotors significantly increased the whole plant dry weight at the end of the research period: $\mathrm{GA}_{3}$ - by $93 \%, 1-\mathrm{NAA}$ - by $69 \%$, 6-BAP - by $44 \%$ compared to the control. Retardants EW-250 and CCC-750 had practically no effect on the whole plant dry weight, while 2CEPA reduced it by $37 \%$ (see Table 1 ).

According to published data, an increase in the plant dry weight was observed after treatment with $\mathrm{GA}_{3}$ in oil flax [8], sugarcane [29], and wheat [32]. The whole wheat plant dry weight also increased under the IAA and NAA treatment [32]. The ryegrass plants fresh and dry weights were increased by the retardants paclobutrazol, CCC [33], and duckweed - by uniconazole [34]. The ethylene producer esphon reduced the tomato plants weight [21].

In addition to the leaf surface area, another important index of the photosynthetic apparatus performance is the chlorophyll content in the leaves. It was established that treatment with anti-gibberellin preparations significantly increased the chlorophyll amount in tomato plants leaves. This index was the highest after the EW-250 treatment - the chlorophyll content increased by $44 \%$ compared to the control (Fig. 7), after 2-CEPA - by $26 \%$, while after CCC-750 there was only a tendency to increase (by $7 \%$ ).

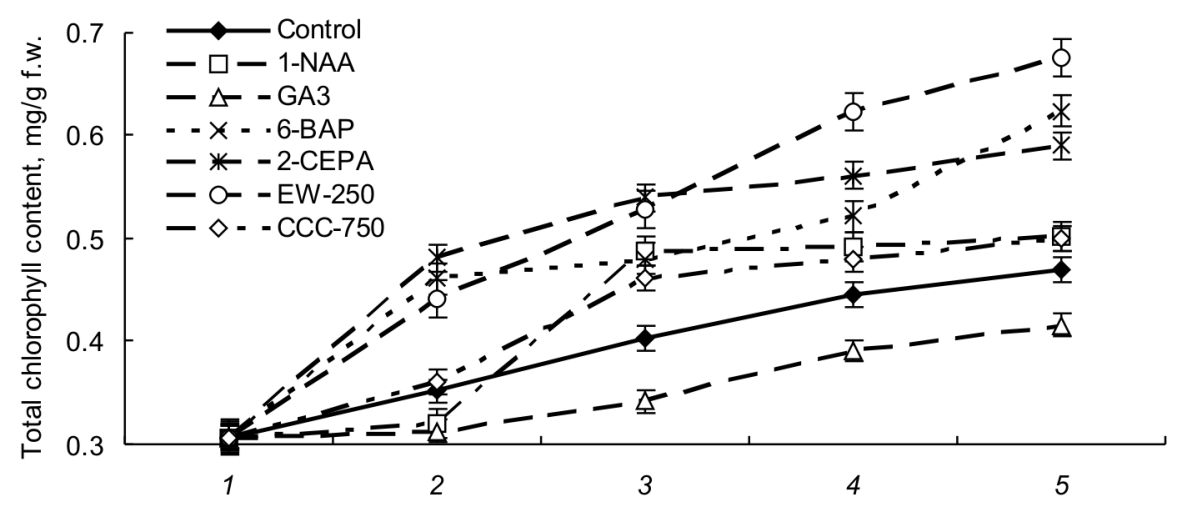

Fig. 7. Effect of growth regulators on the total chlorophyll content in the leaves of tomato plants (plants were treated at the budding stage on June 08, 2019):

1 - day of treatment; $2-10$ th day after treatment; $3-20$ th day after treatment; $4-30$ th day after treatment; $5-40$ th day after treatment 
The 6-BAP growth promotor also increased the total chlorophyll content in the leaves by $33 \%$. After the 1-NAA application, the increase was not significant, and under the influence of $\mathrm{GA}_{3}$, this index decreased by $11 \%$.

These effects are consistent with published data on the influence on photosynthetic pigments content in leaves when using growth regulators in other crops. Thus, an increase in the chlorophyll content under the influence of 6-BAP was observed in leaves of maize [7], wheat [32] and cucumber [35]. Cytokinin growth promotors emistim $\mathrm{C}$ and treptolem increased the chlorophyll content in leaves of oil poppy [5]. The use of retardants also increased the chlorophyll content in leaves, in particular, chloromequate chloride increased the total chlorophyll content in sunflower leaves [28], and tebuconazole - in tomato leaves [12]. At the same time, under the influence of $\mathrm{GA}_{3}$, the content of main photosynthetic pigments decreased [12].

The leaf mesostructural organization largely determines the plant photosynthetic apparatus effectiveness and thereby significantly affects its productivity. According to published data, the plants treatment with growth regulators in most cases leads to a change in leaves anatomical structure. In particular, leaves thickening due to assimilation parenchyma was observed under the paclobutrazol influence on potato plants [11], sugar beet [10], and rape [13]. In all of the above cases, the columnar parenchyma cells volume also increased. In tomato plants, tebuconazole and gibberellic acid also increased the chlorenchyma thickness and the columnar parenchyma cells volume [12]. Thickening of leaves due to mesophyll tissues was observed in maize plants under the influence of 6-benzyladenine growth promotor [7]. Similar results were obtained on oil poppy plants after treatment with emistim $\mathrm{C}$ and treptolem [5]. At the same time, in sunflower plants, treptolem had practically no effect on the chlorenchyma thickness, and the retardant chloromequate chloride significantly increased it with a simultaneous increase in the columnar parenchyma cells volume [36].

The results of our studies indicate that both among growth-promoting and among growth-inhibiting compounds were those that increased the chlorenchyma thickness in the leaves of Bobcat hybrid tomato plants (see Table 2). The largest increase in the main photosynthetic tissue thickness was after the application of EW-250, 6-BAP and CCC-750 - by 22, 18 and $10 \%$, respectively. The influence of other growth regulators on this index was insignificant. At the same time, all growth regulators, except 6BAP, reduced the upper leaf epidermis cells thickness by $18-30 \%$. Growth promotors $\mathrm{GA}_{3}$ and 6-BAP increased the size of the spongy parenchyma cells, and 1-NAA and retardants practically did not affect this index. All growth regulators, except 2-CEPA, increased the volume of columnar parenchyma cells. The most effective in this case was the use of EW-250 and CCC-750 retardants, and 6-BAP growth promotor. Almost all growth regulators significantly increased the epidermal cells number, and the stomata number per leaf abaxial surface area unit.

It is known that plant productivity depends not only on the photosynthetic apparatus structural features, but also on its activity [37, 38]. Our results of measurements of gas exchange rate in tomato leaves treated with growth regulators indicate that by the end of the flowering stage only 6BAP significantly increased the net assimilation rate, and under the EW- 
250 influence there was a tendency to increase this index (Table 3). Though, at the beginning of the fruit formation stage, all growth regulators, except 1-NAA, significantly increased the net assimilation rate. The most effective was the effect of $\mathrm{GA}_{3}, 6$-BAP and EW-250. Under the influence of CCC-750 and 2-CEPA anti-gibberellins, the increase was less, but also significant. The scientific literature contains information on the photosynthetic processes intensification under the influence of both growth promotors [9, 35, 39], in particular gibberellin-like compounds [8], and anti-gibberellin preparations [14, 34, 40].

All growth regulators, except 1-NAA, simultaneously with the intensification of photosynthetic processes at the stage of fruit formation onset, enhanced photorespiration rate (see Table 3). On the one hand, this can be explained by the fact that photosynthetic $\mathrm{CO}_{2}$ assimilation and photorespiration are manifestation of the carboxylase and oxygenase activities of the same enzyme - Rubisco. It is known that the ratio between these activities is quite stable and can change only under significant deviations of external or internal factors from optimal values [41]. For example, with a significant increase or decrease in $\mathrm{CO}_{2}$ concentration, or under severe drought conditions, when photosynthetic processes are inhibited due to the stomata closure [37, 41].

On the other hand, the above results indicate that the treatment of tomato plants with growth regulators in most cases contributed to an increase in the photosynthetic apparatus capacity at the tissue and organ levels, as well as the whole plant, that, undoubtedly, should increase its supply with assimilates, primarily carbohydrates, which, in fact, are the main substrates of respiratory processes. This is indirectly confirmed by a significant dark respiration rate increase at the fruit formation stage under the influence of growth regulators (see Table 3). It can be assumed that the emergence of a new powerful sink stimulated the photosynthetic apparatus activity by demand for assimilates increasing, and activated the respiratory processes in the leaves to provide energy for their transport.

The transpiration rate during the flowering stage under the influence of all growth regulators, except 6-BAP, was less than the control. At the beginning of the fruit formation stage, on the contrary, an increase in this index was observed, except for the variant with 1-NAA. The data obtained suggest that the discussed changes in the net assimilation rate in the experimental variants occurred mainly due to stomatal regulation, as evidenced by an increase in the stomata number per leaf abaxial surface area unit (see Table 2).

The anatomical, morphological, and physiological-biochemical changes in tomato plants under the growth regulators influence positively affected their productivity elements (Table 4). So, all growth promotors and retardants EW-250 and CCC-750 increased the fruits number per plant. Most of all, this index increased after $\mathrm{GA}_{3}$ (by $44 \%$ ) and 6-BAP (by $43 \%$ ) application. 1-NAA increased the fruits number by $14 \%$, EW250 - by $30 \%$, and CCC-750 - by $20 \%$. Under the effect of 2-CEPA, the fruits number was by $4 \%$ less compared to the control.

Under the influence of all growth promotors and CCC-750 retardant, there was only a tendency to increase the fruits diameter in tomato plants. EW-250 significantly increased the average fruit size, and 2CEPA - reduced. 


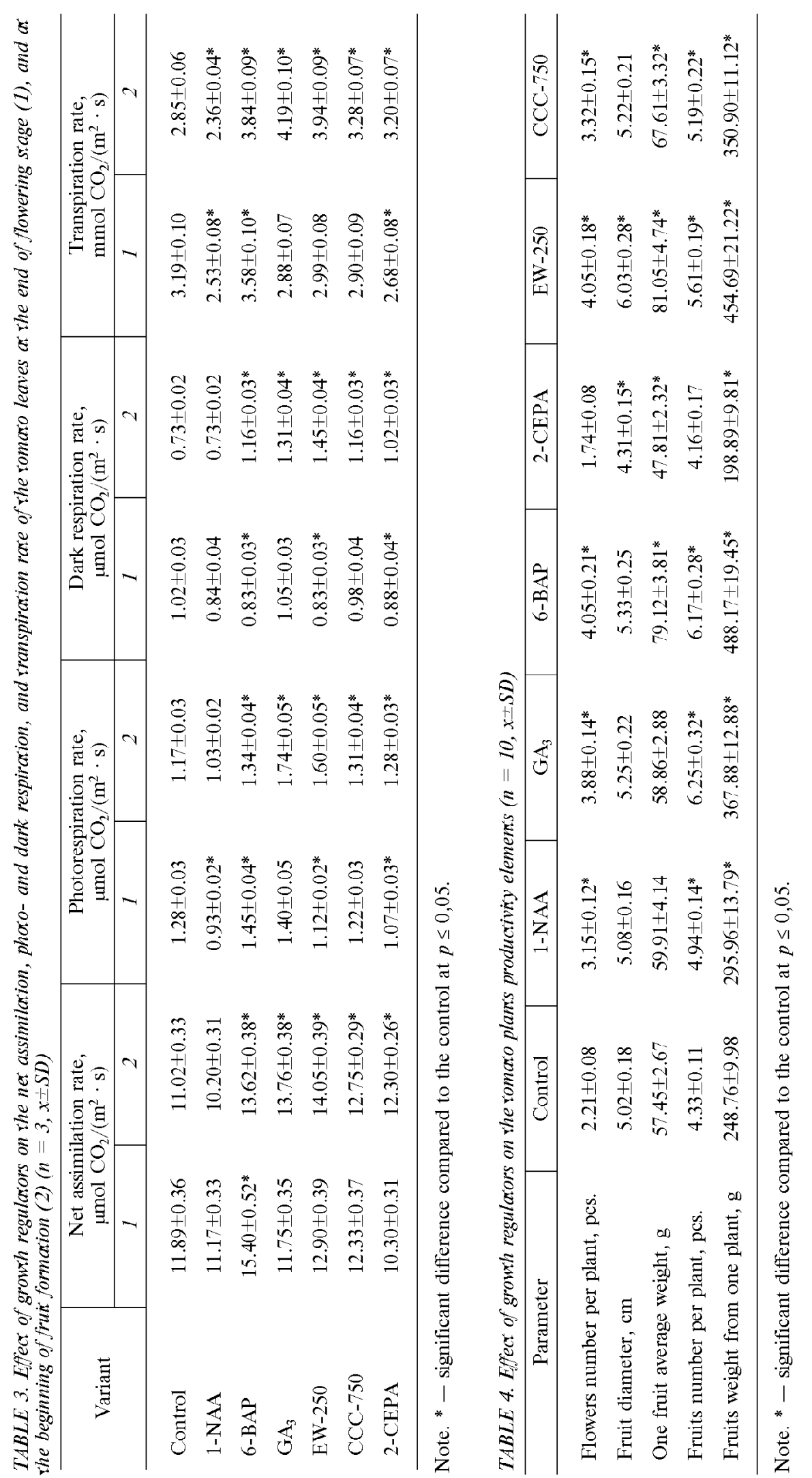


The highest productivity indices were obtained in plants treated with 6-BAP and EW-250. With the application of these preparations, the weight of one fruit increased compared to the control by 38 and $41 \%$, respectively, and plant productivity - by 96 and $83 \%$, respectively. Under the effect of 1-NAA and $\mathrm{GA}_{3}$, the weight of one fruit increased insignificantly, but due to an increase in their number, plant productivity increased by 19 and $48 \%$, respectively. After CCC-750 treatment, the increase in these indices was 18 and $41 \%$. 2-CEPA reduced both the average fruit weight (by $17 \%$ ) and overall productivity (by $20 \%$ ).

Fruit yield from the plant increased most after the use of the triazole derivative retardant EW-250 and the cytokinin growth promotor 6-BAP. So, the increase in plant productivity was obtained both with the application of growth promotor and retardant, the possibility of which was mentioned in the introduction. This is explained by the functioning in a plant organism of wide network of regulatory and signaling mechanisms, the effect on individual links of which can lead to similar results. In the case of cytokinin nature growth promotor effect, this is the stimulation of cell division, the intensification of photosynthesis, the delay in aging, which enhances the supply of plants with assimilates, increases their mass, and, given that harvest index is stable, it leads to an increase in the fruits weight. In the case of retardant applying, the plant vegetative parts growth is limited, however, the leaves mesostructure improves and the chlorophyll content in them increases, which contributes to the intensification of $\mathrm{CO}_{2}$ assimilation by leaf surface area unit. As a result, the supply of plants with assimilates is also increased, which, under conditions of limiting the growth of vegetative parts, are redistributed in the plant source-sink system to the fruits. From a physiological point of view, this path seems more rational. The absence of a positive result from treatment with ethylene producer can be explained by the accelerated aging of the plant under these conditions, which leveled its effect as a retardant, since it reduced the time of photosynthetic apparatus functioning and fruits filling.

Thus, the application of growth regulators with a different action mechanisms on tomato plants under the conditions of pot experiment changed the growth processes rate, influenced the leaves structure, caused changes in the plant source-sink system and the photosynthetic apparatus functioning. In most cases (except for the use of ethylene producer), this contributed to increasing the crop productivity. The most effective was the application of the triazole derivative retardant - tebuconazole (EW-250), and the cytokinin growth promotor - 6-BAP.

\section{REFERENCES}

1. Morgun, V.V., Yavorska, V.K. \& Dragovoz, I.V. (2002). The problem of growth regulators in the world and its solution in Ukraine. Fiziologiya i biokhimiya cult. rastenii. 34, No. 5, pp. 371-375 [in Ukrainian].

2. Kuryata, V.G. (2009). Retardants are modifiers of the hormonal status of plants. In Plant physiology: problems and prospects of development, Vol. 1, (pp. 565-589), Kyiv: Logos [in Ukrainian].

3. Hrytsaienko, Z.M., Ponomarenko, S.P., Karpenko, V.P. \& Leontiuk, I.B. (2008). Biologically active substances in crop production. Kyiv: ZAT Nichlava [in Ukrainian].

4. Sugiura, D., Sawakami, K., Kojim, M., Sakakibara, H., Terashima, I. \& Tateno, M. (2015). Roles of gibberellins and cytokinins in regulation of morphological and physio- 
logical traits in Polygonum cuspidatum responding to light and nitrogen availabilities. Functional Plant Biology, 42(4), pp. 397-409. https://doi.org/10.1071/FP14212 18

5. Polyvanyi, S.V. (2018). Anatomic and morphological characteristics of leaf apparatus construction of oil poppy under the action of growth stimulant. Naukovi zapysky Ternopilskoho derzhavnoho pedahohichnoho universytetu. Seriia: Biolohiia, No. 3-4, pp. 21-27 [in Ukrainian].

6. Khodanitska, O.O. \& Kuryata, V.G. (2011). The effect of treptolem on seed yield and quality characteristics of flaxseed oil. Kormy i kormovyrobnyctvo, 70, pp. 54-59 [in Ukrainian].

7. Ren, B., Zhang, J., Dong, S., Liu, P. \& Zhao, B. (2017). Regulations of 6-benzyladenine (6-BA) on leaf ultrastructure and photosynthetic characteristics of waterlogged summer maize. J. Plant Growth Regul., 36(3), pp. 743-754. https://doi.org/ 10.1007/s00344-017-9677-7

8. Khan, M.N. \& Mohammad, F. (2013). Effect of GA3, N and P ameliorate growth, seed and fibre yield by enhancing photosynthetic capacity and carbonic anhydrase activity of linseed. Integrative Agriculture, 12(7), pp. 1183-1194. https://doi.org/10.1016/S20953119(13)60443-8

9. Luo, Y., Yang, D., Yin, Y., Cui, Z., Li, Y., Chen, J., Zheng, M., Wang, Y., Pang, D., Li, Y. \& Wang, Z. (2016). Effects of exogenous 6-BA and nitrogen fertilizers with varied rates on function and fluorescence characteristics of wheat leaves post anthesis. Scientia Agricultura Sinica, 49(6), pp. 1060-1083. https://doi.org/10.3864/j.issn.05781752.2016.06.004

10. Kuryata, V.G., Shevchuk, O.A., Kiriziy, D.A. \& Gulyaev, B.I. (2002). Structural and functional organization of sugar beet leaf by the action of retardants. Fiziologiya $\mathrm{i}$ biokhimiya cult. rastenii, 34, No. 1, pp. 11-16 [in Ukrainian].

11. Tkachuk, O.O. (2015). Influence of Paclobutrazol on the Anatomical and Morphological Indices of Potato Plants. Lesya Ukrainka Eastern European National University Scientific Bulletin. Series: Biological Sciences, No. 2, pp. 47-50. https://doi.org/ 10.29038/2617-4723-2015-302-47-50 [in Ukrainian].

12. Rogach, V.V., Kravets, O.O., Buina, O.İ. \& Kuryata, V.G. (2018). Dynamic of accumulation and redistribution of various carbohydrate forms and nitrogen in organs of tomatoes under treatment with retardants. Regul. Mech. Biosyst., 9(2), pp. 293-299. doi: 10.15421/021843 [in Ukrainian].

13. Rogach, V.V., Kuryata, V.G. \& Polyvanyi, S.V. (2016). The effect of retardants on morphogenesis, productivity and composition of higher fatty acids of winter rapeseed oil. Vinnitsa: TOV «Nilan-LTD» [in Ukrainian].

14. Yooyongwech, S., Samphumphuang, T., Tisarum, R., Theerawitaya, C. \& Chaum, S. (2017). Water-deficit tolerance in sweet potato (Ipomoea batatas (L.) Lam.) by foliar application of paclobutrazol: role of soluble sugar and free proline. Front Plant Sci., 8, 1400. https://doi.org/10.3389/fpls.2017.01400

15. Poprotska, I.V., Kuryata, V.G., Polyvanyi, S.V., Golunova, L.A. \& Prysedsky, Y.G. (2019). Effect of gibberellin and retardants on the germination of seeds with different types of reserve substances under the conditions of skoto- and photomorphogenesis. Biologija, 65, No. 4, pp. 296-307.

16. Rohach, V.V. \& Rohach, T.I. (2015). Influence of synthetic growth stimulators on morphological and physiological characteristics and biological productivity of potato culture. Visn. Dnipropetr. Univ. Ser. Biol. Ekol., 23(2), pp. 221-224. https://doi.org/ 10.15421/011532 [in Ukrainian].

17. Kuriata, V.G., Rohach, V.V., Rohach, T.I. \& Khranovska, T.V. (2016). The use of antigibberelins with different mechanisms of action on morphogenesis and production process regulation in the plant Solanum melongena (Solanaceae) Visn. Dnipropetr. Univ. Ser. Biol. Ekol., 24(1), pp. 221-224. https://doi.org/10.15421/011628

18. Rogach, V.V., Poprotska, I.V. \& Kuryata, V.G. (2016). Effect of gibberellin and retardants on morphogenesis, photosynthetic apparatus and productivity of the potato. Visn. Dnipropetr. Univ. Ser. Biol. Ekol., 24(2), pp. 416-420. https://doi.org/10.15421/011656 [in Ukrainian].

19. Kuryata, V.H., Rogach, V.V., Buina, O.I., Kushnir, O.V. \& Buinyi, O.V. (2017). Impact of gibberelic acid and tebuconazole on formation of the leaf system and functioning of source-sink plant system of solanaceae vegetable crops. Regul. Mech. Biosyst., 8(2), pp. 162-168. https://doi.org/10.15421/021726 [in Ukrainian]. 
20. Rohach, V.V. (2017). Influence of growth stimulants on photosynthetic apparatus, morphogenesis and production process of eggplant (Solanum melongena). Biosyst Divers., 25(4), pp. 297-304. https://doi.org/10.15421/011745 [in Ukrainian].

21. Kravets, O.O. (2019). Physiological bases of growth regulation and morphogenesis of tomatoes under gibberellin and retardants treatment (Unpublished candidate thesis). Institute of Plant Physiology and Genetics National Academy of Sciences of Ukraine, Kyiv, Ukraine [in Ukrainian].

22. Kazakov, Ye.O. (2000). Methodological bases of the experiment on plant physiology. Kyiv: Fitosotsiotsentr [in Ukrainian].

23. Mokronosov, A.T. \& Borzenkova, R.A. (1978). Methodology for the quantitative assessment of the structure and functional activity of photosynthetic tissues and organs. Trudy po prikladnoj botanike, genetike i selekcii, 61, No. 3, pp. 119-131 [in Russian].

24. Kuryata, V.G. (1998). The effect of retardants on the mesostructure of raspberry leaves. Fiziologiya i biokhimiya cult. rastenii, 30, No. 2, pp. 144-149 [in Russian].

25. Gavrilenko, V.F., Ladygina, M.E. \& Handobina, M.N. (1975). Great workshop on plant physiology. Moscow: Vysshaja shkola [in Russian].

26. Mokronosov, A.T. \& Kovalev, A.G. (Eds.) (1989). Photosynthesis and bioproductivity: methods of determination. Moscow: Agropromizdat [in Russian].

27. Yan, Y., Wan, Y., Liu, W., Wang, X., Yong, T. \& Yang, W. (2015). Influence of seed treatment with uniconazole powder on soybean growth, photosynthesis, dry matter accumulation after flowering and yield in relay strip intercropping system. Plant Production Science, 18(3), pp. 295-301. https://doi.org/10.1626/pps.18.295

28. Rogach, T.İ. \& Kuryata, V.G. (2018). Physiological bases of regulation of morphogenesis and productivity of sunflower by means of chlormequat chloride and treptolem. Vinnitsa: TVORY [in Ukrainian].

29. Rai, R.K., Tripathi, N., Gautam, D. \& Singh, P. (2017). Exogenous application of ethrel and gibberellic acid stimulates physiological growth of late planted sugarcane with short growth period in sub-tropical Indian J. Plant Growth Regul., 36 (2), pp. 472-486. https://doi.org/10.1007/s00344-016-9655-5

30. Mao, J.-P., Zhang, D., Zhang, X., Li, K., Liu, Z., Meng, Y., Lei, C. \& Han, M.-Y. (2018). Effect of exogenous indole-3-butanoic acid (IBA) application on the morphology, hormone status, and gene expression of developing lateral roots in Malus hupehensis. Scientia Horticulturae, 232, pp. 112-120. https://doi.org/10.1016/j.scienta.2017.12.013

31. Zheng, R., Wu, Y. \& Xia, Y. (2012). Chlorocholine chloride and paclobutrazol treatments promoto carbohydrate accumulation in bulbs of Lilium Oriental hybrids «Sorbonne». J. Zhejiang Univ. Sci. B., 13(2), pp. 136-144. https://doi.org/ 10.1631/jzus.B1000425

32. Zhao, H., Cao, H., Ming-Zhen, P., Sun, Y. \& Liu, T. (2017). The role of plant growth regulators in a plant aphid parasitoid tritrophic system. J. Plant Growth Regul., 36(4), pp. 868-876. https://doi.org/10.1007/s00344-017-9689-3

33. Kasem, M.M. \& Abd El-Baset, M.M. (2015). Studding the Influence of Some Growth Retardants as a Chemical Mower on Ryegrass (Lolium perenne L.). Journal of Plant Sciences, 3(5), pp. 255-258. https://doi.org/10.11648/j.jps.20150305.12

34. Liu, Y., Fang, Y., Huang, M., Jin, Y., Sun, J., Tao, X., Zhang, G., He, K., Zhao, Y. \& Zhao, H. (2015). Uniconazole-induced starch accumulation in the bioenergy crop duckweed (Landoltia punctata) I: transcriptome analysis of the effects of uniconazole on chlorophyll and endogenous hormone biosynthesis. Biotechnol. Biofuels, 8, p. 57. https://doi.org/10.1186/s13068-015-0246-7

35. Xiaotao, D., Yuping, J., Hong, W., Haijun, J., Hongmei, Z., Chunhong, C. \& Jizhu, Y. (2013). Effects of cytokinin on photosynthetic gas exchange, chlorophyll fluorescence parameters, antioxidative system and carbohydrate accumulation in cucumber (Cucumis sativus L.) under low light. Acta Physiol Plant., 35(5), pp. 1427-1438. https://doi.org/ $10.1007 / \mathrm{s} 11738-012-1182-930$

36. Rogach, T.İ. (2012). Effect of mixture of chlormequat-chloride and treptolem on morphogenesis and productivity of sunflower. Zbirnyk naukovykh prats VNAU, Seriia: Silskohospodarski nauky, 1(57), pp. 121-127 [in Ukrainian].

37. Kiriziy, D.A., Stasik, O.O., Pryadkina, G.A. \& Shadchina, T.M. (2014). Photosynthesis. Vol. 2. Assimilation of $\mathrm{CO}_{2}$ and the mechanisms of its regulation. Kyiv: Logos [in Russian]. 
38. Stasik, O.O., Kiriziy, D.A. \& Pryadkina, G.A. (2016). Photosynthesis and crop productivity. Fiziol. rast. genet., 48, No. 3, pp. 232-251. https://doi.org/ 10.15407/frg2016.03.232 [in Russian].

39. Mesejo, C., Rosito, S., Reig, C., Martinez-Fuentes, A. \& Agusti, M. (2012). Synthetic auxin 3,5,6-TPA provokes Citrus clementina (Hort. ex Tan) fruitlet abscission by reducing photosynthate availability. J. Plant Growth Regul., 31(2), pp. 186-194. https:// doi.org/10.1007/s00344-011-9230-z

40. Zhang, W., Xu, F., Cheng, H., Li, L., Cao, F. \& Cheng, S. (2013). Effect of chlorocholine chloride on chlorophyll, photosynthesis, soluble sugar and flavonoids of Ginkgo biloba. Notulae Botanicae Horti Agrobotanici Cluj-Napoca, 41(1), pp. 97-103. https:// doi.org/10.15835/nbha4118294

41. Stasik, O.O. (2014). Photorespiration: Metabolism and the physiological role. In Modern photosynthetic problems, Vol. 2, (pp. 505-535), Moskva-Izhevsk: Institute of Computer Research [in Russian].

Received 02.06.2020

\title{
ВПЛИВ СТИМУЛЯТОРЇВ РОСТУ І̇ РЕТАРДАНТЇВ НА МОРФОГЕНЕЗ, ФОТОСИНТЕЗ І ПРОДУКТИВНІСТЬ ТОМАТЇВ (LYCOPERSICON ESCULENTUM MILL.)
}

\author{
В.В. Рогач ${ }^{\text {, Д.А. Кірізій }}$, О.О. Стасик², С. Міцкевічус³ ${ }^{3}$ T.І. Рогач1
}

${ }^{1}$ Вінницький державний педагогічний університет імені Михайла Коцюбинського 21100 Вінниця, вул. Острозького, 32, Україна e-mail: rogachv@ukr.net

${ }^{2}$ Їнститут фізіології рослин і генетики Національної академії наук України 03022 Київ, вул. Васильківська, 31/17, Україна

${ }^{3}$ Університет Вітовта Великого, Факультет природничих наук

44404 Каунас, вул. Вілійська, 8-212, Литва

Вивчали особливості ростових процесів, формування листкового апарату, його мезоструктури і фотосинтетичної активності, а також біологічну продуктивність у рослин томатів гібрида Бобкат під впливом синтетичних аналогів гормонівстимуляторів - 1-нафтилоцтової кислоти (1-НОК), гіберелової кислоти $\left(\Gamma_{3}\right), 6$ бензиламінопурину (6-БАП) і ретардантів - хлормекватхлориду (ССС-750), тебуконазолу (EW-250), есфону (2-ХЕФК), що різняться за механізмом дії. Виявлено, що стимулятори росту підвищували, а ретарданти знижували висоту рослин томатів. Встановлено, що 1-НОК, ГК ${ }_{3}$ і ССС-750 збільшували кількість листків на рослині, тоді як за обробки 2-ХЕФК показник був меншим від контрольного, а за дії EW-250 практично не змінювався. Всі регулятори росту, крім 2-ХЕФК, збільшили кількість листкових пластинок, масу сирої речовини і площу листків. Усі стимулятори росту підвищували масу сухої речовини цілої рослини, тоді як ретарданти EW-250 і CCC750 не впливали на цей показник, а 2-ХЕФК достовірно зменшував його. Всі ретарданти і 6-БАП достовірно збільшили вміст суми хлорофілів у листках томатів,

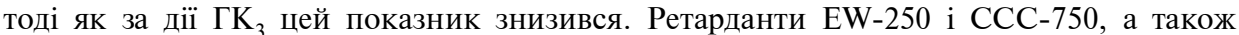
стимулятор 6-БАП сприяли потовщенню хлоренхіми листків томатів, а етиленпродуцент 2-ХЕФК зменшував іiі. За дії всіх регуляторів росту, крім 2-ХЕФК, збільшився об'єм клітин стовпчастої паренхіми. Встановлено, що у фазу початку формування плодів усі регулятори росту, крім 1-НОК, збільшили інтенсивність фотосинтезу, фотодихання, темнового дихання і транспірації. Всі регулятори росту, крім 2-ХЕФК, сприяли підвищенню господарської продуктивності томатів, при цьому ефективним виявилося застосування стимулятора 6-БАП і ретарданту EW-250.

Ключові слова: Lycopersicon esculentum Mill., томати, стимулятори росту, ретарданти, морфогенез, листковий апарат, мезоструктура, хлорофіл, фотосинтез, дихання, продуктивність. 